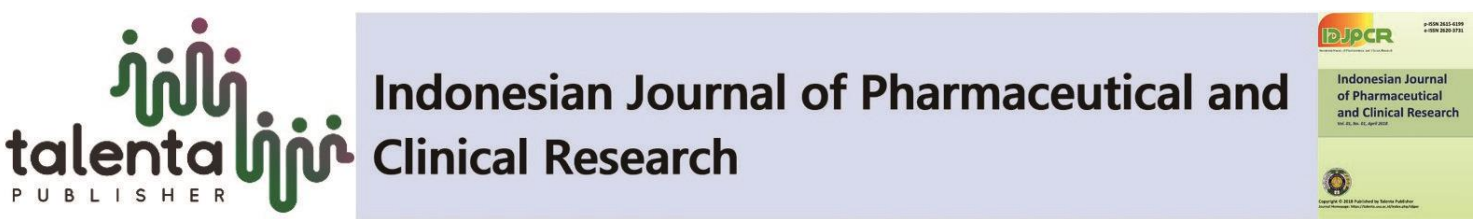

\section{Composition of Fatty Acid and Identification of Lauric Acid Position in Coconut and Palm Kernel Oils}

\author{
Jansen Silalahi, ${ }^{1,2}$ Lida Karo Karo ${ }^{1}$, Siti Morin Sinaga ${ }^{1}$, Yosy Cinthya \\ Eriwaty Silalahi ${ }^{3}$
}

${ }^{1}$ Faculty of Pharmacy, Universitas Sumatera Utara, Medan 20155, Indonesia

${ }^{2}$ Nanomedicine Center, Universitas Sumatera Utara

${ }^{3}$ Department of Pharmacy University of Sari Mutiara Indonesia, Medan 20123, Indonesia

\begin{abstract}
The nutritional value and biochemical properties of oil are measured by the fatty acids composition in oil and the position of fatty acids $(\mathrm{sn}-1,2,3)$ in the triacylglycerol (TAG) molecule. The purpose of this study was to measure the nutritional value based on the fatty acids composition of virgin coconut oil (VCO) and palm kernel oil (PKO), and the position of lauric acid in sn-2. The VCO used was VCO obtained from one of the Pharmacies store in Medan, and PKO from the Oil Processing Plant. The total fatty acid composition was measured by Gas Chromatography. The nutritional value of fat was evaluated by the percentage deviation from $33.33 \%$ (ratio: $1: 1: 1$ ) of each group of fatty acid (saturated fatty acids; SFA: monounsaturated fatty acids; MUFA:polyunsaturated fatty acid (PUFA). The distribution of lauric acid in TAG was conducted through hydrolysis by using specific lipase enzymes active at sn-1,3 positions, so that free fatty acids and 2monoacylglycerol were produced from one TAG molecule. Then free fatty acids were determined by Gas Chromatography. The distribution of lauric acid at sn-2 position was the difference between total lauric acid on TAG before hydrolysis and free lauric acid from sn1.3 position after hydrolysis. The results showed that PKO nutritional value was better (deviation of $95.29 \%$ ) compared to nutritional value of VCO (deviation of 118.55\%). Lauric acid in sn-2 position from VCO and PKO were 48.33and 48.59\% respectively.
\end{abstract}

Keywords: virgin coconut oil, palm kernel oil, composition of fatty acids, sn-2 position, lauric acids

\begin{abstract}
Abstrak. Nilai gizi dan sifat biokimia minyak diukur oleh komposisi asam lemak dalam minyak dan posisi asam lemak (sn-1,2,3) dalam molekul triasilgliserol (TAG). Tujuan dari penelitian ini adalah untuk mengukur nilai gizi berdasarkan komposisi asam lemak dari virgin coconut oil VCO) dan palm kernel oil (PKO), dan posisi asam laurat di sn-2. VCO yang digunakan adalah VCO yang diperoleh dari salah satu apotek di kota Medan, dan PKO dari pabrik pengolahan minyak. Komposisi total asam lemak diukur dengan Gas Chromatography. Nilai gizi lemak dievaluasi dengan persentase penyimpangan dari 33,33\% (rasio: 1: 1: 1) dari masing-masing kelompok asam lemak (saturated fatty acids; SFA: monounsaturated fatty acids; MUFA:polyunsaturated fatty acid (PUFA). Distribusi asam laurat dalam TAG dilakukan melalui hidrolisis dengan menggunakan enzim lipase spesifik yang aktif pada posisi sn-1,3, sehingga asam lemak bebas dan 2-monoasilgliserol dihasilkan dari satu molekul TAG, kemudian asam lemak bebas ditentukan dengan Gas Chromatography. Distribusi asam laurat pada posisi sn-2 terletak pada perbedaan antara total asam laurat pada TAG sebelum hidrolisis dan asam laurat bebas dari posisi sn-1.3 setelah hidrolisis. Hasil penelitian ini menunjukkan bahwa nilai gizi PKO lebih
\end{abstract}

${ }^{*}$ Corresponding author at: Faculty of Pharmacy, Universitas Sumatera Utara, Medan, Indonesia

E-mail address: jansen@usu.ac.id 
baik karena nilai deviasi yang lebih kecil (95,29\%)) dibandingkan dengan nilai gizi VCO dengan deviasi yang lebih besar yaitu (118,55\%). Distribusi asam laurat dalam posisi sn-2 dari VCO dan PKO adalah 48,33 dan 48,59\% berturut-turut.

Kata kunci: virgin coconut oil, palm kernel oil, komposisi Asam lemak, posisi sn-2 asam laurat

Received 25 September 2018 | Revised 15 October 2018 | Accepted 26 November 2018

\section{Introduction}

The nutritional value of oil or fat can be measured based on two aspects, namely the composition of fatty acids in oil or fat and the position of fatty acids in the TAG molecule. The ideal fatty acid composition in the diet recommended that the ratio of saturated fatty acids (SFA), monounsaturated fatty acids (MUFA), and plural unsaturated fatty acids (polyunsaturated fatty acids $=$ PUFA) should be $1: 1: 1$, or 33.3\% each group) [1]

The medical potential of coconut was evaluated by Jon Kabara in the 1970s, namely antibacterial, antiviral and antifungal activity of medium chain fatty acids ( MCFA), especially lauric acid (C12: 0$)$ in the form of monoglyceride (monolaurin or ML) [2,3]. Coconut processed products, such as VCO and PKO are safe for human consumption. The quality of VCO and PKO was measured from MCFA and lauric acid. MCFA content and lauric acid levels were influenced by coconut varieties, the height of the place to grow, and the technology of the manufacturing process. MCFA is easily absorbed into cells then into the mitochondria, so the metabolism is faster. Through the increasing of metabolism, so cells work efficiently, to form new cells and to replace damaged cells faster [4]. VCO and PKO are categorized as medium chain triglyceride (MCT), because the fatty acids are dominated by medium chain lauric acid (C: 12: 0). So that, the metabolism in digestion is also different from long chain triglyceride, thus it can be increased stamina (long chain triglyceride; LCT) [5,6].

The best MCFA antibacterial activity is in the form and monoglyceride. Among of saturated fatty acids, lauric acid found to be bigher antimicrobial activity than caprylic acid (C8: 0), capric acid (C10: 0), and myristic acid (C14: 0). In general, fatty acids and monoglycerides inactivate the bacteria by damaging the plasma membrane (lipid bilayer) of the bacteria $[2,5]$. According to Silalahi [7], the antibacterial activity of triglycerides after hydrolysis with lypase enzymes active specificly on Sn-1,3 positions was more effective than hydrolysis by partial saponification. The results of hydrolysis by saponification could be monoglycerides, diglycerides or even triglycerides were not completely hydolyzed, because the amount of alkali was insufficient to sap all triglycerides. Thus, it could be called partial hydrolysis. Antibacterial properties of the results of partial hydrolysis of VCO and PKO showed that the results of hydrolysis were more effective than without hydrolysis. The antibacterial properties of VCO 
hydrolysis were greater than the results of hydrolyzed PKO. Perhaps, it was due to the difference of distribution lauric acid that contained in triglyceride molecules in VCO and PKO [8].

To obtain monoglycerides from triglycerides that contained in VCO and PKO was done hydrolysis by using specific enzymes that active only on sn-1 and 3 positions in TAG molecules. Specific enzymes that worked in sn-1 and 3 positions are lipase enzymes, but it does not hydrolyze acyl in the sn-2 position, so it resulted in 2-monoacylglycerol (2-MAG) and free fatty acids. Free fatty acids, then changed in the form of methyl ester and injected into Gas Chromatography, so that the percentage of lauric acid in the sn-2 position was the difference between total lauric fatty acids in triacylglycerol and free fatty acids from sn-1,3 positions ${ }^{1}$. The purpose of this study was to analyze the fatty acid composition of VCO and PKO based on the SFA, MUFA, PUFA classes, and to identify the position of lauric acid in fat molecules in VCO and PKO.

\section{Research method}

\subsection{Materials and Reagents}

VCO samples were obtained from Pharmacy in Medan City, and PKO was obtained from one of the Oil Industries in Asahan. Boron trifluoride, sodium hydroxide,Trishydroxymethylaminomethane, n-hexane, ethanol, methanol, sodium chloride, anhydrous sodium sulfate, calcium chloride, specific lipase at sn-1,3 position (Lipozyme ${ }^{\circledR}$ TL IM), fatty acid methyl ester (FAME) standard of C:8- C:22. [9].

\subsection{Analysis of Fatty Acid Composition}

Two hundreds and fifty (250) $\mathrm{mg}$ of oil was weighed in a closed test tube, then added $5 \mathrm{ml}$ of $0.5 \mathrm{~N}$ methanolic sodium, then shaken for one minute. The tube was tightly closed and heated at $100^{\circ} \mathrm{C}$ in a water bath for five minutes, then cooled to a temperature between $30-40{ }^{\circ} \mathrm{C}$. Added $6 \mathrm{ml} \mathrm{BF} 3$ in methanol and closed the tube again, then heated it at $100^{\circ} \mathrm{C}$ in water bath for five minutes. Then, cooled to $30-40{ }^{\circ} \mathrm{C}$ and then added $10 \mathrm{ml}$ of $\mathrm{n}$-hexane and shaked for thirty seconds. $15 \mathrm{ml}$ of saturated $\mathrm{NaCl}$ solution was added, so that two layers were formed, namely the water layer and n-hexane layer. The n-hexane layer was separated, so that there was only the water layer remained. The water layer was extracted again with $5 \mathrm{ml}$ of $\mathrm{n}$-hexane, and combined with the first $\mathrm{n}$-hexane layer. N-hexane extract was added with $500 \mathrm{mg}$ of Na2So4 anhydrous and left for 15 minutes. Water free hexane was injected as much as $1 \mu \mathrm{L}$ into the chromatography gas $[1,9]$. The identification of fatty acids was conducted based on the retention time, while the determination of the levels based on the peak area of each the fatty acid, then it was divided by the total peak area multiplied by $100 \%$. So that the fatty acid composition in the sample could be obtained [9]. 


\subsection{Evaluation of Nutrition Value}

The nutritional value of the oil was evaluated by measuring the \% value of the total deviation from the absolute value $(\Delta)$ of the difference in the percentage of each class of fatty acids in the fat of each class of fatty acids with an ideal value (33.33\%) with the following formula.\% Deviation $(\Delta)=\mid 33.33 \%$ - $\%$ SFA $|+| 33.33 \%$ - $\%$ MUFA $|+| 33.33 \%$ - $\%$ PUFA $\mid$ If the value of $\Delta$ is 0 then the oil has the good nutritional value, the greater the deviation the worse the nutritional value is [1].

\subsection{Determination of the Distribution Of Lauric Acid in sn-2 Position}

Hydrolysis was done on VCO and PKO by weighing 6 grams of oil in a $125 \mathrm{ml}$ erlenmeyer, added $10 \mathrm{ml}$ of distilled water, $2.5 \mathrm{ml}$ of $\mathrm{CaCl} 20.063 \mathrm{M}, 5 \mathrm{ml}$ of tris- $\mathrm{HCl}$ buffer solution, 100 $\mathrm{mg}$ of lipase, then incubated at $37 \pm 0.5^{\circ} \mathrm{C}$ with incubation time for 8 hours. Shaking was done every 1 hour, as long as 10 minutes, then deactivated with $50 \mathrm{ml}$ of ethanol. The mixture was transferred into a separating funnel, shaken and allowed to stand until two layers were formed. The top layer (fatty acid) was taken and added with $50 \mathrm{ml}$ of ethanol and then the top layer was collected, then it was evaporated on a water bath in a container. Then, $250 \mathrm{mg}$ was taken, to be processed into a methylester form as described above (Silalahi) [1.9]. The water-free liquid phase was injected as much as $1 \mu \mathrm{L}$ in gas chromatography. The difference in weight of lauric acid before and after hydrolysis with enzymes was the weight of lauric acid in the sn-2 position [1.9]. Lauric acid weight in the sample was determined by the following equation:

Lauric acid weight $(\mathrm{mg} / \mathrm{mg}$ sample $)=$ Correction factor $\times$ Area of lauric acid Note:correction factor $=$ Results for standard lauric acid weight with the area of standard lauric acid.

\section{Results and Discussion}

\subsection{Fatty Acid Composition in VCO and PKO}

The fatty acid composition of the analysis results in VCO and PKO can be seen in Table 1.

Table 1. Fatty acids Composition in VCO and PKO

\begin{tabular}{lllcc}
\hline & \multicolumn{2}{l}{ Fatty Acids } & \multirow{2}{*}{ Composition of fatty acids on the sample (\%b/b) } \\
\hline \multirow{2}{*}{ Group } & Symbol & Fatty acids & & \\
\cline { 3 - 5 } & & & VCO & PKO \\
\hline SFA & C 6:0 & Caproic & 0.48 & 0.16 \\
\cline { 2 - 5 } & C 8:0 & Caprilic & 6.94 & 2.87 \\
\cline { 2 - 5 } & C 10:0 & Capric & 5.71 & 2.89 \\
\hline & C 12:0 & Lauric & 48.91 & 48.07 \\
\hline & C 14:0 & Miristic & 18.82 & 16.20 \\
\hline & C 16:0 & Palmitic & 8.94 & 8.48 \\
\hline & C 18:0 & Stearic & 2.73 & 2.15 \\
\cline { 2 - 5 } & C 18:1 & Oleic & 6.05 & 16.37 \\
\hline PUFA & C 18:2 & Linoleic & 1.29 & 2.49 \\
\hline
\end{tabular}


As shown in Table 1 that in VCO and PKO, the high SFA content and lauric acid is the highest among SFA content so that it is solid and whiten at $26^{\circ} \mathrm{C}$ and melts again at $29^{\circ} \mathrm{C}$. In PKO, the SFA content is capric acid (C 10: 0) $2.89 \%$ smaller than the $3.3-4.4 \%$ range. The difference in the composition of fatty acids was influenced by the manufacturing process. For example, VCO products are technically made with a cold process without heating. In the PKO process comprise kernel breaking, isolation, drying processes to produce palm kernel oil. This manufacturing process made the difference, but produced a relatively similar fatty acid composition when compared to literature [11].

\subsection{VCO and PKO Nutritional Value}

From the percentage of fatty acid composition (SFA, MUFA, PUFA) in VCO and PKO, the nutritional value can be obtained based on the deviation from the ideal value.

The nutritional value of VCO and PKO can be seen in Table 2.

Table 2. Nutritional value of VCO and PKO based on the composition of the fatty acid group

\begin{tabular}{|c|c|c|c|c|}
\hline \multirow[t]{2}{*}{ Sample } & \multicolumn{3}{|c|}{$\begin{array}{l}\text { Fatty acids composition } \\
\text { (Deviation of nutritional value) }\end{array}$} & \multirow{2}{*}{$\begin{array}{l}\text { Total of } \\
\text { Deviation } \\
(\%)\end{array}$} \\
\hline & $\begin{array}{l}\text { SFA } \\
(\%)\end{array}$ & $\begin{array}{l}\text { MUFA } \\
(\%)\end{array}$ & $\begin{array}{l}\text { PUFA } \\
(\%)\end{array}$ & \\
\hline VCO & $92.60(59.27)$ & $6.09(27.24)$ & $1.29(32.04)$ & 118.55 \\
\hline PKO & $80.93(47.60)$ & $16.48(16.85)$ & $2.49(30.84)$ & 95.29 \\
\hline
\end{tabular}

The value of nutritional fat based on the ratio between fatty acids SFA, MUFA, and PUFA is $33.3 \%$ for each group. If each of them as much as $33.3 \%$, it means that the deviation is $0 \%$. If there is deviations from $33.3 \%$ of each of them, it would become a deviation from the good nutritional value for each class of fatty acids [1]. From Table 2, it can be seen that PKO nutritional value is better (95\% deviation) than VCO (118\% deviation). Besides that, VCO and PKO are included in MCT which will be quickly digested and entered the liver through the portal vein and then oxidized to energy without being converted to be fat again. So it will not enter the blood circulation as fat. Through these characteristics, the body temperature will increase (thermogenesis), so that the stored fat is included metabolized and hence reduce obesity and reduce the risk of type 2 diabetes [5]. MCT will also be able to increase HDL and therefore reduce the risk of coronary heart disease.

Besides of based on the composition of fatty acids, nutritional value was also measured by the type of fatty acids and their position in the TAG, because they were related to the metabolic mechanisms in the body. For example, long chain saturated fatty acids, especially palmitic and myristic acids in the sn-2 position will be more atherogenic than when in sn-1.3 positions. 
Because if palmitic and myristic acid is at the sn 1.3 , it will be hydrolyzed in the intestine and react to calcium and magnesium in the intestine to become insoluble and unabsorbed salt, then excreted through feaces. So that, to examine the nutritional value of VCO and PKO, it was also important to evaluate the distribution of fatty acid types in the triacylglycerol molecule $[1,5]$

\subsection{Lauric Acid Distribution at Sn-2 Position}

VCO and PKO were hydrolyzed with the lipase enzyme as the body hydrolyzes oil. Before and after hydrolysis, the sample was esterified, so that it became fatty acid methyl ester, and then analyzed by Chromatography gas. Fatty acids found in sn-2 position were obtained from total fatty acid and after hydrolysis. The percentage distribution of lauric acid in VCO and PKO can be seen in Table 3.

Table 3. The percentage distribution of lauric acid in VCO and PKO

\begin{tabular}{ccccc}
\hline Sample & \multicolumn{4}{c}{ Distribution of Lauric Acid on TAG *) } \\
\cline { 2 - 5 } & $\begin{array}{c}\text { Total } \\
\text { weight }(\mathbf{g})\end{array}$ & $\begin{array}{c}\text { Weight on } \\
\text { position } \\
\mathbf{s n - 2}(\mathbf{g})\end{array}$ & $\begin{array}{c}\text { Distribution on } \\
\text { position } \boldsymbol{s} \mathbf{- 2}(\boldsymbol{\%})\end{array}$ & $\begin{array}{c}\text { Distribution on position } \\
\mathbf{s n - 1 , 3}(\boldsymbol{\%})\end{array}$ \\
\hline VCO & 1.20 & 0.62 & 48.33 & 51.67 \\
\hline PKO & 1.42 & 0.73 & 48.59 & 51.41 \\
\hline
\end{tabular}

Note:*) The result is an average of three times the repeated injections of the sample. Sample weight: 6 grams of oil.

Based on Table 3, the weight of lauric acid in the VCO is at sn-2 position less than that of PKO. lauric acid weight does not numerically difference in the sample. The short chain fatty acids which are abundant at sn-1.3 position, can directly enter the liver through the portal vein and metabolised rapidly into energy. Whereas long chain fatty acids in the sn-1.3 position can not all be absorbed, because they reacte with calcium and magnesium to form salts that are not soluble in water and excreted from the body through feces [5,12].

The results of another research showed that the hydrolysis method can increase antibacterial activity, and the enzymatic method was better than the saponification method, where the results of enzymatic hydrolysis were lauric acid and monolaurin, whereas the resulting hydrolysis of lauric acid was lauric acid, monolaurin or dilaurine or may be some fixed in the form of triglycerides [6].

The best MCFA antibacterial activity is in the free form and monoglyceride. Triglycerides and diglycerides are not effective as antibacterials. From all of saturated fatty acids, lauric acid has better antimicrobial activity than caprylic acid (C8: 0), capric acid (C10: 0), and myristic acid 
(C14: 0). Generally, it was reported that fatty acids and monoglycerides inactivated bacteria by damaging the plasma membrane (lipid bilayer) of these bacteria $[2,12,13]$.

Monolaurin has advantages compared to other antibacterials, where monolaurin is only effective toward pathogenic bacteria, not for beneficial probiotic bacteria. Monolaurin showed antibacterial characteristics toward Staphylococcus aureus and Mycobacterium terrae, but did not show antibacterial activity toward Escherichia coli and Klebsiella pneumonia [14].

\section{Conclusion}

The composition of fatty acids in VCO and PKO is dominated by saturated fatty acids (SFA) with deviations in nutritional values of $118.55 \%$ and $95.29 \%$ respectively. This data suggest that PKO's nutritional value is better than VCO. The distribution of lauric acid in the fat molecule at sn-2 position in VCO and PKO showed that the lauric acid content in sn-2 position is not different as many as $48.33 \%$ and $48.59 \%$

\section{REFERENCES}

[1] Y.C.E. Silalahi, "Fatty Acid Composition and Identification of the Position of Palmitic Acid in Some Animal and Vegetable Oils", Theses. Universitas Sumatera Utara,Medan, Indonesia, 2011.

[2] J. J. Kabara, D. M. Swieczkowski, A. J. Conley, and J. P. Truant, "Fatty Acids and Derivatives as Antimicrobial Agents," Antimicrobial Agents and Chemotherapy, vol. 2, no. 1, pp. 23-28, Jul. 1972.

[3] S.D. Conrado, "Coconut Oil In Health And Disease: Its And Monolaurin's Potential As Cure For HIV/AIDS", Cocotech Meeting Chennai, 2000

[4] N. Sari, "Effect of Giving Virgin Coconut Oil (VCO) on Immunohistochemical Profile of Antioxidant Superoxide Dismutase (SOD) in Kidney Mellitus Mice Tissue", Theses. Institut Pertanian Bogor, Indonesia. 2009.

[5] M.G. Enig, "Health and Nutritional Benefits from Coconut Oil: An Important Functional Food for the $21^{\text {st }}$ Century". AVOC Lauric Oil Symposium. Ho Chi Min City. Vietnam. 1996.

[6] J. Silalahi, D. Pertiwi, A. Dalmuthe, and Y.C.E. Silalahi, "Effect of Acute Consumption of Coconut Oil and Palm Oil on Swimming Capacity Endurance of Mice (Mus musculus)". Int J Pharm Tech Res, vol.8, no.9, pp. 55-59. 2015.

[7] J. Silalahi, J., M.P. Yade, D. Effendy, "Antibacterial Activity of Hydrolyzed Virgin Coconut Oil”, Asian J Pharm Clin Res, vol. 7, no.2, pp. 90-94. 2014

[8] F.S. Luong, J. Silalahi,D. Suryanto, "Antibacterial Activity of Enzymatic Hydrolyzed of Virgin coconut Oil and Palm Kernel Oil Against Staphylococcus aureus, Salmonella typhi and Escherichia coli. Int J Pharm Tech Res. vol. 6, no. 2, pp. 628-633.2014

[9] American Oil Chemists'Society (AOCS), "Official methods and recommended practices of the American Oil Chemists' Society. AOCS: Preparation of Methyl Esters of Fatty Acids Champaign", AOCS Press, pp. 2-66. 1997.

[10] B. Satiawihardja, Study of Making Artificial Brown Butter from Palm Oil with Enzymatic Interesterification Process. Jurnal Teknologi Indonesia Pertanian. vol.10 no.3, pp. 129-138, 2001.

[11] R.D. O'Brien, Fats and Oils: Formulating and Prossesing for Applications". $3^{\text {rd }}$ Edn, CRC Press, London, pp. 43-47, 273. 2009.

[12] M.G.Enig, "Health and Nutrition Benefits from Coconut Oil and Its Advantages Over Competing Oils", Indian Coconut Jurnal, vol. 2, no. 3, pp. 9-15. 2010 
[13] G. Widiyarti, M. Hanafi, and W.P. Suwarso,"Study on The Synthesis of Monolaurin as Antibacterial Agent Against Staphylococcus aureus", Indon.. J. Chem.; vol. 9, no.1, pp. 99-106. 2009

[14] S. Lieberman, M. G. Enig, and H. G. Preuss, "A Review of Monolaurin and Lauric Acid: Natural Virucidal and Bactericidal Agents," Alternative and Complementary Therapies, vol. 12, no. 6, pp. 310-314, Dec. 2006. 